\title{
DESENTRALISASI PENGELOLAAN WILAYAH PESISIR DAN LAUTAN DALAM KERANGKA PRINSIP NEGARA KEPULAUAN
}

\author{
Dhiana Puspitawati
}

\author{
Fakultas Hukum Universitas Brawijaya \\ Jl. MT. Haryono 169 Malang \\ Email: dhiana@ub.ac.id, dhiana74@yahoo.com.au
}

\begin{abstract}
The development of ocean management emerged during the United Nations Conference on Environment and Development 1992 (UNCED). UNCED produced what known as Rio Declaration, which introduced a wider, sustainable and integrated approach in managing the environment and this includes ocean space. As a result, Indonesia has produced Indonesian Act 32/2004 on Regional Autonomy, which devolves the management of coastal zone to provincial administration $u / p$ to 12 nautical miles from the coastal shoreline, and one-third of the provincial administration is under local government administration. Further development was the enactment of Indonesian Act 27/2007 on the Management of Coastal Areas and Small Islands, which provides regulations on coastal areas zoning which will be conducted by regional as well as local government.

This paper will analyse the legal conformity between national law on coastal management (as regulated under Act 32/2004 and Act 27/2007) with archipelagic states principles provided by international law (Part IV of the Law of the Sea Convention 1982). It is argued that the ground norm of archipelagic state principles was restoring the function of the ocean as unifying factor of Indonesian people for optimal utilization of ocean resources. On the other hand, the implementation of Act 32/2004 and Act 27/2007 raised conflicts, especially conflicts between traditional fishermen, which transform the function of the ocean as dividing factor of Indonesian people. Thus, it is argued that in ocean management more emphasized on the groun norm of archipelagic state principles should be done. In addition, a new system and corresponding sets of values for policy formulation and implementation must be created.
\end{abstract}

Key words: integrated, sustainability, decentralized coastal zone management, archipelagic state

\begin{abstract}
Abstrak
Perkembangan pengelolaan wilayah laut dimulai pada saat diadakannya United Nations Conference on Environment and Development(UNCED) pada tahun 1992. UNCED menghasilkan Deklarasi Rio (Rio Declaration) berisi tentang prinsip-prinsip pengaturan serta pengelolaan wilayah laut modern, dimana diakui adanya pendekatan baru yang mengedepankan prinsip keterpaduan (integrated) dan keberlangsungan (sustainability) dalam pengelolaan wilayah laut. Sehubungan dengan hal tersebut, Indonesia mengeluarkan Undang-Undang Nomor 32 Tahun 2004 tentang Pemerintahan Daerah (UU 32/2004), yang memberikan kewenangan pengelolaan wilayah pesisir dan lautan sebesar maksimal 12 mil laut kepada pemerintah propinsi, sedangkan pemerintah kabupaten/kota diberi kewenangan pengelolaan wilayah pesisir dan lautan sebesar $1 / 3$ wilayah pesisir yang diberikan kepada pemerintah propinsi. Selanjutnya Undang-Undang Nomor 27 Tahun 2007 tentang Pengelolaan Wilayah Pesisir dan Pulau-Pulau Kecil mengatur
\end{abstract}


tentang zonasi wilayah pesisir yang harus dilakukan oleh pemerintah daerah.

Tulisan ini akan menganalisa kesesuaian norma hukum antara UU 32/2004 serta UU 27/2007, dengan prinsip negara kepulauan yang diatur dalam ketentuan hukum internasional. Norma dasar prinsip negara kepulauan adalah mengembalikan fungsi laut di Indonesia sebagai sarana pemersatu bangsa guna pemanfaatan sumber daya laut secara optimal untuk kepentingan bersama secara merata. Sementara itu pelaksanaan UU 32/2004 dan UU 27/2007 memunculkan banyak konflik, terutama konflik antar nelayan yang mengarah kepada berubahnya fungsi laut di Indonesia, bukan lagi sebagai sarana pemersatu melainkan sebagai sarana pemisah. Dengan demikian, dalam pelaksanaan desentralisasi pengelolaan wilayah pesisir dan lautan diperlukan suatu penekanan pada nilai-nilai dan norma yang melandasi prinsip negara kepulauan; serta diperlukan suatu mekanisme tersendiri yang dapat meminimalisir munculnya konflik.

Kata kunci: integrated, sustainibilty, desentralisasi pengelolaan wilayah pesisir dan lautan, prinsip negara kepulauan

\section{Latar Belakang}

Perkembangan kodifikasi hukum laut internasional diawali dengan Konferensi Internasional tentang Hukum Laut I atau dikenal dengan United Nation Conference on the Law of the Sea I (UNCLOS I) pada tahun 1958, yang dilanjutkan dengan UNCLOS II pada tahun 1960. UNCLOS II kemudian dilanjutkan dengan UNCLOS III yang berlangsung selama hampir 10 tahun (tahun 1973-1982). Pada UNCLOS III inilah akhirnya Konvensi Hukum Laut Internasional atau yang kemudian dikenal dengan United Nations Convention on the Law of the Sea 1982 atau Konvensi PBB tentang Hukum Laut, disingkat UNCLOS 1982, diadopsi. UNCLOS 1982 ini selanjutnya diratifikasi oleh Pemerintah Republik Indonesia dengan Undang-Undang Nomor 17 Tahun 1985, tentang Pengesahan UNCLOS 1982. UNCLOS 1982 menggunakan pendekatan menyeluruh dan inklusif yang menganggap bahwa semua permasalahan tentang penggunaan wilayah laut saling berhubungan dan perlu dipikirkan secara utuh. ${ }^{1}$ Sejak itulah, peranan laut sebagai penyedia sumber daya alam guna mendukung peningkatan kesejahteraan manusia semakin meningkat dan penting. Sehingga, mengarah kepada pembangunan dan pemanfaatan laut secara berkelanjutan (in sustainable manner).

Sementara itu, pada tanggal 3-14 Juni 1992 di Rio de Jainero diadakan United Nations Conference on Environment and Development (UNCED 1992) atau biasa disebut dengan KTT Bumi. UNCED 1992 merupakan bentuk kepedulian negaranegara akan pentingnya mempertahankan lingkungan hidup untuk pembangunan berkelanjutan (sustainable development). Dalam UNCED 1992 dihasilkan beberapa kesepakatan, antara lain, yang relevan dengan tulisan ini, adalah Deklarasi Rio dan Agenda 21. Berkenaan dengan masalah laut, UNCED 1992 memperkenalkan pendekatan baru

1 Lihat de Merffy, Anick, Tata Kelola Laut: Suatu Proses pada Arah yang Tepat untuk Pengelolaan Wilayah Laut yang Efektive ("Ocean governance: A Process in the Right Direction for the Effective Management of the Oceans"), 18 Ocean Yearbook, 2004, page 163, 165. 
dalam pengelolaan wilayah laut yaitu melalui pendekatan yang lebih luas, berkelanjutan dan terintegrasi. Prinsip pengelolaan wilayah laut secara terintegrasi atau dikenal dengan integrated ocean governance principles mulai dikenalkan dalam UNCED 1992 dan dituangkan dalam Agenda 21.

Sebagai pencetus konsep negara kepulauan, hingga akhirnya diakui sebagai prinsip negara kepulauan dalam Bab IV UNCLOS 1982, ${ }^{2}$ Indonesia sangatlah peduli dengan pemanfaatan dan pengelolaan wilayah laut. Alhasil, integrated ocean governance principles, yang menitikberatkan pada pembangunan laut secara berkelanjutan, diimplementasikan oleh Indonesia dengan dirumuskannya pembagian kewenangan pengelolaan wilayah pesisir dan lautan kepada pemerintah daerah sebagaimana diatur dalam Undang-Undang Nomor 32 Tahun 2004 tentang Pemerintahan Daerah (UU 32/2004) yang selanjutnya diikuti dengan dikeluarkannya Undang-Undang No 27 Tahun 2007 tentang Pengelolaan Wilayah Pesisir dan Pulau-Pulau Kecil. Dalam penerapaannya, kedua undang-undang tersebut telah menyebabkan konflik akan pemanfaatan sumber daya laut, terutama konflik antar nelayan. Tidak samanya kondisi geografis serta ketersediaan sarana dan prasarana antara satu daerah dengan daerah lain di Indonesia telah menyebabkan timpangnya pemanfaatan sumber daya laut. Hal ini tentunya tidak sejalan dengan norma yang melandasi dicetuskannya prinsip negara kepulauan, yang menekankan pada fungsi laut sebagai sarana pemersatu bangsa serta pentingnya kesatuan wilayah daratan dan perairan bagi Indonesia guna pemanfaatan sumber daya alam secara merata untuk kepentingan bersama bangsa Indonesia.

Tulisan ini akan menganalisa kesesuaian norma hukum antara pengaturan kewenangan pemerintah daerah dalam mengelola wilayah pesisir dan lautan sebagaimana diatur dalam UU 32/2004 serta zonasi wilayah pesisir yang diatur dalam UU 27/2007, dengan prinsip negara kepulauan yang diatur dalam ketentuan hukum internasional. Metode yang digunakan dalam menganalisa permasalahan adalah yuridis-normatif dengan pendekatan statute approach. Pengelolaan wilayah pesisir dan lautan di Indonesia memerlukan suatu penekanan pada nilai-nilai dan norma yang melandasi prinsip negara kepulauan; serta memerlukan suatu mekanisme tersendiri yang dapat meminimalisir munculnya konflik.

2 Prinsip negara kepulauan dilandasi dengan norma akan pentingnya kesatuan wilayah darat dan lautan bagi Indonesia dalam rangka optimalisasi pemanfaatan sumber daya alam secara merata dan optimal bagi seluruh rakyat Indonesia. Prinsip ini bertujuan untuk mengembalikan fungsi laut sebagai sarana pemersatu sebagaimana kondisi sebelum dijajah oleh Belanda. Di bawah pemerintahan Belanda, laut disekeliling dan diantara pulaupulau Indonesia berfungsi sebagai pemisah sebagaimana dituangkan dalam ketentuan Maritim Hindia Belanda atau yang dikenal dengan Territoriale zee Maritieme Kringan Ordonantie 1939 (TZMKO/Kringen Ordonantie 1939). 


\section{Pembahasan}

\section{A. Ketentuan Internasional tentang Pengelolaan Wilayah Pesisir dan \\ Lautan}

Terdapat beberapa ketentuan internasional yang mengatur tentang pengelolaan wilayah pesisir dan lautan, diantaranya, sebagaimana disebutkan di atas, yaitu meliputi UNCED, Deklarasi Rio serta Agenda 21. Akan tetapi, sebelum membahas tentang pengelolaan wilayah pesisir, suatu negara pantai harus menentukan zona-zona maritimnya terlebih dahulu. Berkaitan dengan zona maritim, UNCLOS 1982 membagi wilayah laut ke dalam kewenangan negara pantai dengan derajat yang berbeda yang dapat mengimbangi hak negara lain untuk mendapatkan akses ke wilayah laut serta ikut memanfaatkan laut. Menurut UNCLOS 1982, suatu negara pantai serta negara kepulauan berhak atas wilayah laut selebar 12 mil laut dari garis pangkal, yang disebut sebagai laut teritorial, ${ }^{3}$ dimana kedaulatan negara pantai dan/ negara kepulauan diperpanjang hingga wilayah laut ini. Walaupun demikian kedaulatan negara pantai dan/ negara kepulauan tidak tak terbatas atau dengan kata lain dibatasi oleh hak lintas damai kapal asing. ${ }^{4}$ Setelah wilayah laut teritorial, negara pantai dan/ negara kepulauan mempunyai hak berdaulat atas wilayah laut selebar 24 mil laut diukur dari garis pangkal, yang disebut dengan zona tambahan. ${ }^{5}$ Negara pantai dan/ negara kepulauan mempunyai hak berdaulat atas zona tambahan, yaitu kewenangan untuk memberlakukan aturan tentang imigrasi, sanitasi dan pajak. ${ }^{6}$ Setelah zona tambahan, negara pantai dan negara kepulauan mempunyai hak berdaulat atas zona ekonomi eksklusif atau yang dikenal dengan ZEE, yaitu wilayah laut selebar 200 mil laut diukur dari garis pangkal atau $188 \mathrm{mil}$ laut diukur dari batas terluar laut teritorial ${ }^{7}$ Pada ZEE negara pantai dan negara kepulauan hanya mempunyai hak berdaulat (sovereign rights), ${ }^{8}$ yaitu kewenangan untuk melakukan eksplorasi dan eksploitasi sumber daya laut, khususnya sumber daya hayati. Berbeda dengan laut teritorial, pada wilayah ZEE berlaku rejim pelayaran bebas. ${ }^{9}$ Setelah ZEE , zona maritim berikutnya adalah laut bebas. Berkenaan dengan dasar laut, negara pantai dan/ negara kepulauan juga berhak atas landas kontinen (continental shelf), yaitu dasar laut dan tanah dibawahnya dari daerah di bawah permukaan laut yang terletak di luar laut teritorialnya sepanjang kelanjutan alamiah wilayah daratannya hingga pinggiran luar tepi kontinen, atau hingga suatu jarak 200 mil laut dari garis pangkal darimana lebar laut teritorial

3 Pasal 3 KHL 1982.

4 Pasal 17 UNCLOS 1982.

5 Pasal 33 UNCLOS 1982.

6 Pasal 33 UNCLOS 1982.

7 Pasal 55 UNCLOS 1982

8 Pasal 56 UNCLOS 1982.

9 Pasal 58 UNCLOS 1982. 
diukur, dalam hal pinggiran luar tepi kontinen tidak mencapai jarak tersebut. ${ }^{10}$ Suatu negara dapat menambah luas landas kontinennya selebar 150 mil laut sehingga menjadi 350 mil laut, dengan suatu persyaratan khusus. ${ }^{11} \mathrm{Di}$ landas kontinen ini negara pantai dan/ negara kepulauan dapat melakukan eksplorasi dan eksploitasi sumber daya alam non-hayati.

Ketentuan-ketentuan UNCLOS 1982 yang secara ekstensif diterapkan di Indonesia adalah ketentuan-ketentaun yang berkaitan dengan zona maritim serta hak lintas. ${ }^{12}$ Hal tersebut terus-menerus dilakukan Indonesia sebagai bentuk komitmen Indonesia terhadap prinsip negara kepulauan, hingga pada tahun 1992 diadakan United Nations Conference on the Environment and Development (UNCED 1992). Salah satu kesepakatan yang dicapai dalamUNCED adalah Deklarasi Rio. Deklarasi ini memperkenalkan suatu pendekatan baru dalam pengelolaan lingkungan, yaitu melalui pendekatan yang lebih luas, terpadu serta berkelanjutan dengan prioritas penanganan masalah lingkungan, yang intinya adalah untuk meningkatkan kerjasama internasional. Berkenaan dengan lingkungan laut, Indonesia juga berkeinginan untuk menerapkan tata kelola laut dengan pendekatan yang terintegrasi dan berkelanjutan dengan tetap berpedoman pada prinsip negara kepulauan.
Selanjutnya, mengamati pola peraturan perundangan Indonesia yang berkaitan dengan pengaturan wilayah laut, dapat dilihat bahwa dalam kurun waktu sebelum diadopsinya UNCLOS 1982 hingga era tahun 1992, tata kelola laut di Indonesia lebih diarahkan pada pendekatan teritorial. Hal ini dapat dipahami karena pada awal adopsi UNCLOS 1982 Indonesia berkeinginan untuk menunjukkan komitmen Indonesia dalam menerapkan prinsip negara kepulauan. Akan tetapi, seiring dengan munculnya pendekatan pembangunan yang berkelanjutan dan terintegrasi untuk lingkungan, termasuk lingkungan laut, tata kelola laut di Indonesia mulai menuju ke arah pembangunan kebijakan nasional kelautan dengan tetap berpegang teguh pada prinsip negara kepulauan. ${ }^{13}$

\section{B. Pengelolaan Wilayah Pesisir yang Terdesentralisasi (Desentralized Coastal Zone Management)}

Indonesia telah melakukan banyak pembaharuan terhadap pengaturan masalah kelautannya termasuk pengelolaan tentang wilayah laut. Sejak dikeluarkannya UndangUndang Nomor 32 Tahun 2004, pemerintah provinsi dan kabupaten/kota diberikan otonomi yang lebih besar, termasuk juga dalam hal pengelolaan wilayah pesisir.

10 Pasal 76 UNCLOS 1982.

11 Dalam perkembangannya, suatu negara pantai dan/kepulauan dapat mengklaim lebih dari 350 mil laut landa kontinen dari garis pangkal, dengan syarat sedimen di landa kontinen sejauh itu dapat dibuktikan sama dengan sedimen negara pantai. Lihat Pasal 76 (6) UNCLOS 1982.

12 UU 6/1996 tentang Perairan Indonesia, UU 5/1983 tentang ZEE.

13 Lihat Dhiana, Puspitawati, The Concept of an Archipelagic State and its Implementation in Indonesia, $\mathrm{PhD}$ Dissertation, University of Queensland, 2008. Lihat pula, Dino Patti, Djalal, The Geopolitics of Indonesia's Maritime Territory Policies, 1996. 
Kebijakan yang demikian, selanjutnya disebut desentralisasi pengelolaan wilayah pesisir atau disebut juga Decentralization of Coastal Zone Management (selanjutnya disebut DCZM).

Desentralisasi merupakan suatu konsep yang luas dalam strategi pembangunan dan pengelolaan, ${ }^{14}$ yang juga meliputi pengelolaan sumber daya alam. ${ }^{15}$ Terdapat banyak definisi desentralisasi, yang dalam pengertian luasnya, fokus pada sistem tingkatan pemerintah dan strategi pembagian kekuasaan. Diantara berbagai macam definisi yang ada, terdapat setidaknya tiga intepretasi atau tiga pengertian yang secara umum diterima, yaitu pengertian yang dikeluarkan oleh Perserikatan Bangsa-Bangsa (PBB) pada UN Report, Decentralization for national and local development in 1962;16 definisi oleh Rondinelli and Cheema; ${ }^{17}$ serta definisi yang dikeluarkan oleh World Bank. ${ }^{18}$ Menurut UN's Report of 1962, desentralisasi dapat diartikan sebagai:
"[T]he transfer of authority on a geographic basis whether by deconcentration (i.e. delegation) of administrative authority to fields units of the same department or level of government or by the political devolution of authority to local government units or special statutory bodies. "19

Kunci utama dalam berbagai macam definisi yang ada terletak pada adanya pendelegasian kekuasaan dari pemerintah tingkat atas kepada pemerintah tingkat bawahnya. Sebagian besar definisi mengartikan desentralisasi dalam kerangka bagaimana desentralisasi tersebut diterapkan.

Sistem desentralisasi di Indonesia sebenarnya telah ada sejak masa kolonialisasi oleh Belanda. Akan tetapi, pada masa setelah kemerdekaan, tujuan utama Indonesia adalah kesatuan melalui sistem sentralisasi. Upaya

14 Lihat Bennet, R.J., Decentralization: Local Governments and Markets: Towards a Post Welfare Agenda, 1990, Commonwealth Secretariat, Decentralisation for Development: A Bibliography ,1983,; Laugo, J, Forms Decentralisation and their Implications for Education, 1995, 31 Comparative Education 5; Rondinelli, D.A and Cheema, G.S., Implementing Decentralisation Policies: An Introduction, in Cheema, G.S. and Rondinelli, D.A. (eds.), Decentralisation and Development: Policy Implementation in Developing Countries, 1983, 1; Rondinelli, D.A., and Nellis, J.R., Accesing Decentralization Policies in Developing Countries: The Case of Some Cautios Optimism”, 1986, 4 Development Policy Review 3; Samoff, J, Decentralisation: The Politics of Intervention, 1992, 21 Development and Change 513; Smith, B.C., Decentralization: The Territorial Dimension of the State, 1985; Kumssa, A, Edralin, J and Oyugi, W.O., A Needs Assessment Mission Report on Capacity Development in Local Governance: Africa-Asia Co-operation, 2003.

15 Lihat Agrawal, A and Ribot, J.C., Accountability in Decentralization: A Framework with South Asian and African Cases, 1993, 33 Journal of Developing Areas 473; Benjaminsen, T.A., Natural Resource Management, Paradigm Shifts and the Decentralization Reform in Mali, 1997, 25 Human Ecology 121; Ribot, J.C., Democratic Decentralization of Natural Resources: Institutional Choice and Discretionary Powers in Sub-Saharan Africa, 200323 Public Administration and Development 53.

16 United Nations, Decentralization for National and Local Development, ST/TAO/M/19 United Nations, 1962.

17 Cheema and Rondinelli, 1983, above n 13, page 5.

18 World Bank, Decentralization and Subnational Regional Economics - What, Why and Where, in World Bank (ed.) Decentralization and Subnational regional Economics, 2006, page 21.

19 United Nations, 1962, above n 15, page 246. 
sentralisasi dalam pengelolaan wilayah dapat dilihat pada Deklarasi Djuanda 1957 yang mengikat wilayah daratan dan lautan Indonesa ke dalam satu kesatuan. Akan tetapi, sejak terjadinya krisis ekonomi di Asia Timur, termasuk di Indonesia pada tahun 19971998, muncul keluhan dari propinsi yang kaya akan sumber daya tentang insufficient revenue, dan hal ini mendesak pemerintah untuk mengadakan pembaharuan, termasuk permintaan akan otonomi daerah yang lebih besar. Sebagai respon terhadap krisis ekonomi, Indonesia mengeluarkan ketentuan mengenai desentralisasi melalui UU 22/1999. ${ }^{20}$ Undangundang tersebut membagi kekuasaan sebagian besar pada pemerintah propinsi dikarenakan adanya kekhawatiran bahwa daerah yang kuat akan dapat memicu konflik daerah dan politik. $^{21}$

Pembaharuan (reform) desentralisasi di Indonesia meliputi pemberian otoritas dan de-konsentrasi fungsi. Pemberian kekuasaan kepada otoritas propinsi merupakan bentuk yang dominan dari desentralisasi hingga tahun 1999, dimana setelah itu pemberian otoritas beralih kepada pemerintah kota dan kabupaten. Pemerintah daerah mempunyai fungsi yang luas dan menerima substantial intergovernmental transfers, dengan otoritas revenue yang kecil. Setelah itu, negara membuat suatu kerangka hukum, yaitu UU
32/2004 yang merevisi UU 22/1999 dan UU 33/2004. Akan tetapi perimbangan keuangan pusat dan daerah masih membutuhkan pengaturan lebih detail karena tidak diaturnya mekanisme revenue.

Meskipun UU 32/2004 tentang Pemerintahan Daerah mempertinggi kontrol pemerintah akan tetapi meninggalkan aspek penting dari sistem intergovermental. Kapasitas daerah tidak memadai, sumber daya manusia masih berusaha menyesuaikan dengan lingkungan yang lebih demokratis. Hal terpenting terkait dengan fokus tulisan ini adalah desentralisasi pengelolaan wilayah pesisir atau Dezentralised Coastal Zone Management (DCZM). Sistem intergovernmental yang tidak jelas berpotensi sebaliknya dari prinsip negara kepulauan.

UU 32/2004 menyerahkan pengelolaan wilayah pesisir dengan pembagian antara pemerintah propinsi dengan pemerintah kabupaten/kota yang memiliki wilayah pesisir. Menurut pasal 18 (4) UU 32/2004, pemerintah propinsi mempunyai kewenangan untuk mengelola wilayah pesisirnya selebar 12 mil laut dari garis pangkal, ${ }^{22}$ serta sepertiga dari wilayah pengelolaan pemerintah propinsi tersebut diserahkan pengelolaannya pada pemerintah kabupatan/kota. ${ }^{23}$ Pasal 18 ayat (4) mengatur kewenangan wilayah pesisir/lautan bagi pemerintah propinsi dan pemerintah kabupaten/kota sebagai berikut:

20 Lembar Negara, 1999, No. 60, Tambahan Lembar Negara (1999) No. 3839.

21 Baca lebih lanjut Smoke P, Decentralization in East Asia and the Pacific: Making Local Government Work, 2005.

22 Pasal 18 (4) UU 32/2004.

23 Ibid. 


\section{Gambar 1. Ilustrasi Pasal 18 (4) UU 32/2004}

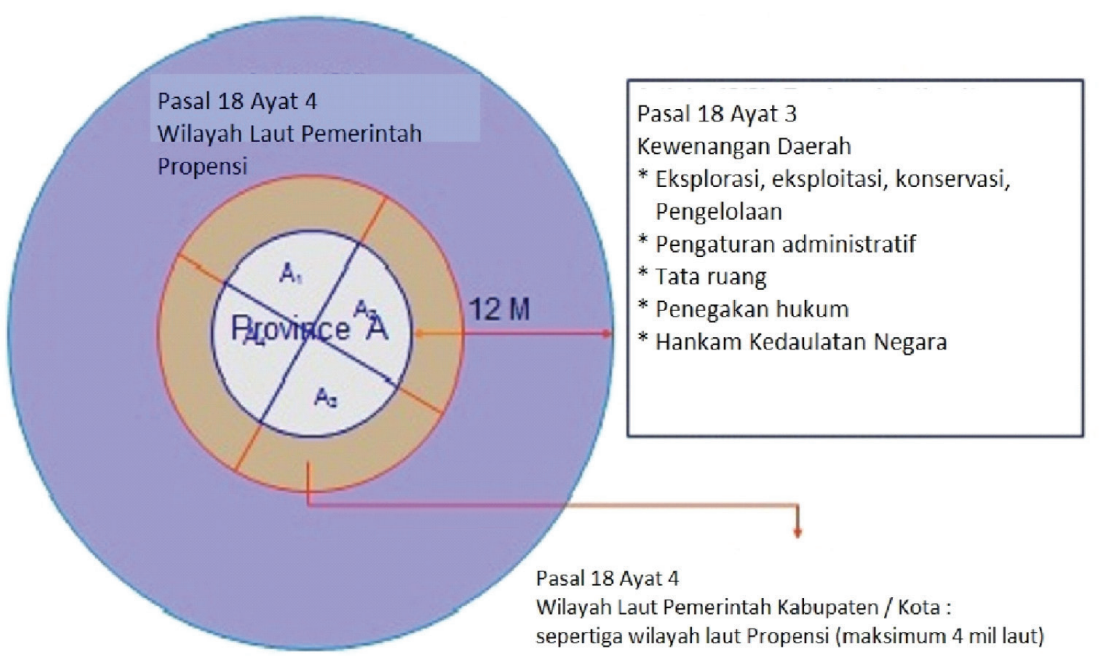

Sumber: Bahan Hukum Sekunder ${ }^{24}$

"Kewenangan untuk mengelola sumber daya di wilayah laut sebagaimana dimaksud pada ayat (3) paling jauh 12 (dua belas) mil laut diukur dari garis pantai ke arah laut lepas dan/atau ke arah perairan kepulauan untuk propinsi dan $1 / 3$ (sepertiga) dari wilayah kewenangan propinsi untuk kabupaten/kota."

Dengan demikian, jika pemerintah propinsi mengklaim 12 mil laut wilayah pesisir/lautannya maka pemerintah kabupaten/ kotanya berwenang atas 4 mil laut wilayah pesisir/lautan. Pengaturan ini diterapkan baik atas perairan kepulauan maupun laut teritorial. Dibawah ini ilustrasi pembagian wilayah laut antara pemerintah propinsi dan pemerintah kabupaten/kota:

Jika, sebagaimana diutarakan sebelumnya bahwa pemerintah kabupatan/kota tidak lagi terikat pada hirarki pemerintah propinsi, akan menimbulkan pertanyaan kepada siapa pemerintah kebupaten/kota akan bertanggungjawab atas pelaksanaan pengelolaan wilayah pesisirnya. Dari pengaturan ini, terlihat seakan-akan pemerintah kabupaten/kota mempunyai kedaulatan penuh akan wilayah pesisirnya, padahal sesungguhnya tidak. Kewenangan pemerintah kabupaten/kota hanya sebatas pengelolaan sumberdaya. Beberapa pemerintah kabupaten/propinsi bahkan sudah ada yang mengeluarkan Peraturan Daerah (Perda) yang lebih menekankan pada revenues daripada masalah ekologi dan prinsip keberlanjutan. Sementara UU 33/2004 tidak mengatur tentang financial revenue antara pemerintah propinsi dan pemerintah kabupaten/kota, konflik pada pengelolaan wilayah pesisir kerap kali muncul. Hal ini

24 Lihat juga Gullet, Warwick, Maritime Law in the Federal Context: Australian and Indonesian Provincial Maritime Zones, makalah dipresentasikan dalam International Seminar and Indonesian Forum on Ocean Law and Resources: Building Comprehensive Perspective on National Security and Sustainable Development, Brawijaya University, 17-19 May 2010. 
disebabkan karena masing-masing institusi terkait dengan wilayah pesisir membuat tujuan, target dan rencana operasional masing-masing yang acapkali tumpang tindih. Sebagian besar sektor yang terkait tidak mempunyai tujuan dan visi yang sama guna keberlanjutan sumberdaya pesisir. Pada kesempatan yang sama, pemerintah kabupaten/kota membuat suatu tujuan yang tidak jelas dikarenakan tidak mempunyai kewenangan yang jelas untuk pengelolaan sumber daya pesisir. Pada banyak hal pemerintah daerah sebenarnya secara financial sangat bergantung pada alokasi pemerintah pusat. ${ }^{25}$

Menurut Pasal 18 ayat (3) UU 32/2004 pemerintah propinsi dan pemerintah kabupaten/kota mempunyai 6 tugas dalam pengelolaan wilayah pesisir secara desentralisasi, yang meliputi:

(i) eksplorasi, eksploitasi, konservasi dan pengelolaan kekayaan laut;

(ii) pengaturan administratif;

(iii) pengaturan tata ruang;

(iv) penegakan hukum terhadap peraturan yang dikeluarkan oleh daerah atau yang melimpahkan kewenangannya oleh Pemerintah;

(v) ikut serta dalam pemeliharaan keamanan dan

(vi) ikut serta dalam pertahanan kedaulatan negara

Sementara itu, menurut undang-undang ini pemerintah pusat juga mempunyai kewenangan penegakan hukum dalam pemeliharaan keamanan serta pertahanan kedaulatan negara. Dengan demikian, bisa dipertanyakan apakah kewenangan antara pemerintah kabupaten/kota dan pemerintah propinsi sebagaimana disebutkan dalam Pasal 18 ayat (3) paragraph iv-vi tidak akan tumpang tindih dengan kewenangan yang dimiliki pemerintah pusat? Lufsiana selanjutnya mengatakan bahwa walaupun UU 32/2004 memberikan kewenangan demikian pada pemerintah kabupaten/kota serta pemerintah propinsi, pengaturan tersebut harus diatur lebih lanjut guna memperjelas pelaksanaan kewenangan tersebut. Dengan demikian, pemerintah kabupaten/kota sebenarnya tidak diberikan kewenangan berkenaan dengan pertahanan keamanan dan kedaulatan karena dalam pelaksanaannya akan sulit dilaksanakan berkaitan dengan badan penegak hukum di laut serta dapat memperluas skala desentralisasi yang tidak sejalan dengan tujuan desentralisasi sesungguhnya atau dengan kata lain desentralisasi yang berlebihan akan membahayakan kesatuan Indonesia sebagaimana ditekankan oleh prinsip negara kepulauan. ${ }^{26}$

Perkembangan selanjutnya dalam pengelolaan wilayah laut adalah dikeluarkannya Undang-undang No 27/2007 tentang Pengelolaan Wilayah Pesisir dan

25 Wawancara dengan Dr. Prasetyo Riyadi, SH, MH, Staf ahli Pemda Surabaya, 10 April 2007.

26 Wawancara dengan Ahmad Dahlan, SH, MAP, Peneliti tentang konsep desentralisasi di Indonesia, 9 April 2007. 
Gambar 2 Ilustrasi Pembagian Wilayah Laut antara 2 Propinsi yang Berhadapan

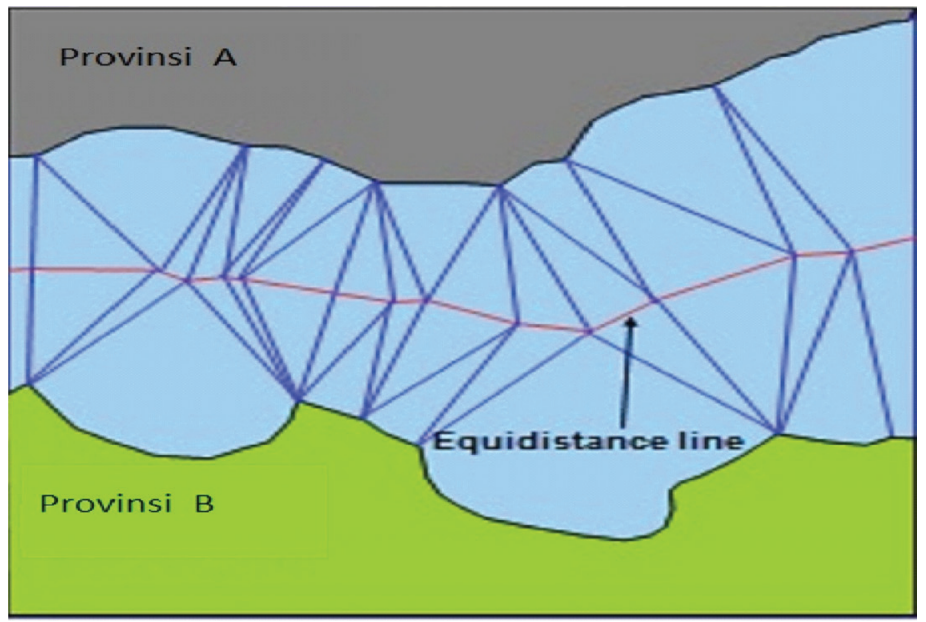

Sumber: Bahan Hukum Sekunder ${ }^{27}$

Gambar 3. Ilustrasi Pembagian Wilayah Laut antara 2 Propinsi yang Bersebelahan

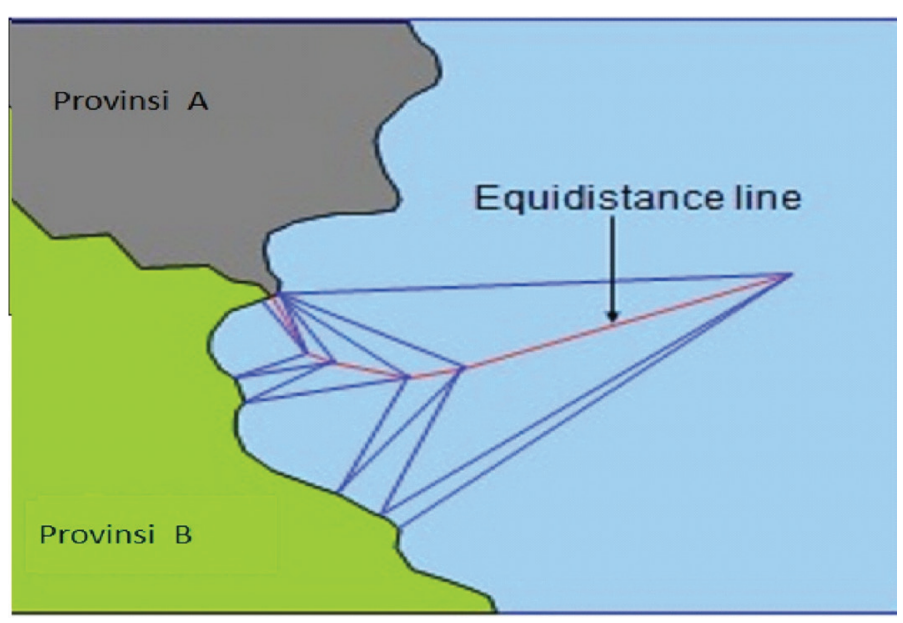

Sumber: Bahan Hukum Sekunder ${ }^{28}$

Pulau-Pulau Kecil (UU 27/2007). Undangundang ini menekankan kembali apa yang diatur dalam UU 32/2004 tentang konsep pengelolaan wilayah pesisir yang terdesentralisasi. Analisa tentang UU 27/2007 akan dijelaskan pada sub bagian dibawah ini.

C. Undang-undang Nomor 27 Tahun 2007 tentang Pengelolaan Wilayah Pesisir dan Pulau-pulau Kecil

Sebagaimana dijelaskan sebelumnya, bahwa UU 27/2007 mengatur tentang

eksplorasi, ekploitasi, konservasi serta pengelolaan kekayaan laut dengan pengaturan lebih detail tentang pengelolaan wilayah pesisir dan pulau-pulau kecil. UU 27/2007 mengatur pengelolaan wilayah pesisir dengan membagi wilayah pesisir ke dalam zona-zona pengelolaan dengan kewenangan masing-masing. Undang-undang ini mewajibkan pemerintah propinsi serta pemerintah kabupaten/kota yang mempunyai wilayah pesisir untuk merumuskan rencana

27 Gullet, Warwick, n 23.

28 Ibid. 
strategis serta rencana zonasi, rencana aksi serta rencana pengelolaan wilayah pesisir. Sebenarnya, konsep DCZM ini bisa dilihat sebagai manifestasi adopsi konsep marine cadastre yang diterapkan dinegara benua/ negara pantai biasa seperti Australia. Sehingga bisa dipertanyakan apakan konsep demikian cocok untuk diterapkan di negara kepulauan yang secara geografis sama sekali berbeda dengan negara benua/negara pantai biasa.

Dalam pelaksanaannya, UU No. 27/2007 tidak dapat berjalan sendiri akan tetapi dibutuhkan suatu peraturan pelaksana. UU No. 27/2007 menyebutkan ada tiga macam peraturan pelaksana yang terdiri dari Peraturan Pemerintah (PP), Peraturan Presiden (Perpres) dan Peraturan Menteri (PerMen). Setidaknya pelaksanaan UU No. 27/2007 membutuhkan empat PP, 10 Perpres dan 12 PerMen. Sebelum UU 27/2007 dapat dilaksanakan, terlebih dahulu harus diadakan pembagian wilayah laut antara propinsi yang satu dengan propinsi yang lain serta antara kabupaten/kota yang satu dengan yang lain yang terbukti sangat sulit dilakukan. Sebagai ilustrasi, dibawah ini digambarkan kompleksitas pembagian wilayah laut antara dua propinsi yang berhadapan serta pembagian wilayah laut antara dua propinsi yang berhadapan:

Selanjutnya, baik UU 32/2004 maupun UU 27/2007 tidak mengatur tentang metode penarikan garis batas maritim untuk pembagian wilayah laut antara satu kabupaten/kota dengan kabupaten/kota lainnya yang berdampingan maupun berhadapan. Dengan demikian, metode line of equidistance bisa digunakan. Prescott mendefinisikan line of equidistance sebagai " a geometrical solution to the division of intervening seas. "29 Selanjutnya, "at every point the line of equidistance is located at the same distance from the nearest point of the baselines of each state. "30 Ini berarti jika metode line of equidistance digunakan diharapkan akan didapatkan wilayah laut yang dianggap sama atau equal. Titik-titik yang membentuk line of equidistance diambil dari titik-titik dengan lokasi yang berjarak sama dengan titik terdekat dari garis dasar masing-masing negara, dalam hal ini masingmasing wilayah propinsi. Akan tetapi, tidak jelas apakah metode ini juga bisa dengan serta merta diterapkan pada dua wilayah propinsi dalam negara yang sama, mengingat metode ini biasanya digunakan dalam hal pembagian wilayah laut antar negara.

UU 32/2004 mengatur bahwa daerah propinsi yang mempunyai wilayah pesisir dapat menguasai (untuk tujuan mengelola) wilayah pesisir dan lautnya selebar 12 mil laut dari garis pantai, sedangkan daerah kabupaten/kota yang mempunyai wilayah pesisir berhak atas $1 / 3$ dari wilayah pesisir yang diklaim oleh pemerintah propinsinya.

29 Prescott, Victor, "East Timor's Potential Maritime Boundaries" in Rothwell, Donald R and Tsamenyi, Martin (eds), The Maritime Dimensions of Independent East Timor, 2000, 79, 80.

30 Ibid. 
Lebih lanjut menurut UU 27/2007 masingmasing pemerintah propinsi dan pemerintah kabupaten/kota tersebut wajib merumuskan Rencana Strategis Wilayah Pesisir dan PulauPulau Kecil (RSWP-3-K), Rencana Zonasi Wilayah Pesisir dan Pulau-Pulau Kecil (RZWP-3-K), Rencana Pengelolaan Wilayah Pesisir dan Pulau-Pulau Kecil (RPWP-3-K), Rencana Aksi Pengelolaan Wilayah Pesisir dan Pulau-Pulau Kecil (RAPWP-3-K), sebagaimana diuraikan dalam pembahasan sebelumnya.

Berdasarkan pengaturan tersebut dan jika dilihat dari ilustrasi gambar diatas, pembagian wilayah pesisir/lautan sebagaimana diatur dalam UU 32/2004 akan sulit untuk diterapkan pada Indonesia yang terdiri dari 33 propinsi. Setelah dibagi, masing-masing propinsi dan kabupaten/kota akan membagi-bagi lagi wilayah lautnya ke dalam zonasi-zonasi sebagaimana diatur dalam UU 27/2007.

\section{Kesesuaian Norma Hukum Internasional dan Nasional tentang Pengelolaan Wilayah Pesisir dan Lautan Terpadu}

Dari uraian dan analisa di atas, dapat dikatakan bahwa dalam pengaturan pengelolaan wilayah laut di Indonesia selalu merujuk pada ketentuan-ketentuan internasional yang ada. Dari sisi kewilayahan Indonesia sebagai pencetus prinsip negara kepulauan selalu mengacu pada Konvensi Hukum Laut 1982. Demikian juga dalam hal pengelolaan sumber daya alam, Indonesia sangat bersemangat dan berkomitmen untuk selalu menjunjung tinggi prinsip keberlanjutan (sustainable principles), hanya saja dalam memformulasikan perundang-undangan tentang pengelolaan wilayah laut dapat dilihat pola yang sangat dipengaruhi oleh otonomi daerah. Sehingga kerapkali terjadi kesulitan dalam pelaksanaan pengelolaan wilayah laut terutama berkenaan dengan zonasi wilayah laut secara desentralisasi atau yang biasa disebut dengan Desentralized Coastal Zone Management (DCZM).

Walaupun sistem pemerintahan desentralisasi dianggap paling cocok untuk diterapkan di suatu negara dengan wilayah yang sangat luas seperti Indonesia, desentralisasi pada pengelolaan wilayah laut dan sumber daya kelautan terbukti menimbulkan konflik dalam pelaksanaannya. Disamping itu, desentralisasi pengelolaan wilayah laut menyebabkan terjadinya 'pengkavlingan' laut yang tidak sejalan dengan prinsip dasar pengelolaan wilayah laut di Indonesia, yaitu prinsip negara kepulauan, yang menekankan pada kesatuan antara wilayah darat dan lautan. Dari analisa yang sudah dilakukan, kesulitan dalam penerapan DCZM adalah adanya ketidaksesuaian dalam pengadopsian metode pembagian wilayah. DCZM merupakan konsep yang berawal dari konsep marine cadastre yang biasa diterapkan di negara pantai biasa atau bahkan negara benua dengan sistem pemerintahan federal. Tentu saja jika diterapkan pada negara kepulauan dengan bentuk negara 
kesatuan akan dijumpai hambatan-hambatan dalam pelaksanaannya. Dari gambar 3 yang menunjukkan ilustrasi penerapan Pasal 18 ayat (4) UU 32/2004 dan penerapan UU 27/2007 dapat dilihat bahwa akan ada tumpang tindih kewenangan pengelolaan wilayah laut yang dapat berdampak pada konflik sektoral yang jika dibiarkan akan mengarah pada ancaman terhadap kesatuan negara Indonesia.

Dengan demikian, bisa dikatakan bahwa dalam pengelolaan wilayah pesisir/ lautan di Indonesia walaupun sudah ada kesesuaian antara norma hukum nasional dan norma hukum internasional, kesesuaian tersebut masih bersifat sektoral, padahal dalam pengelolaan wilayah laut diperlukan pendekatan yang lebih global dan terintegrasi.

\section{Simpulan}

Dari uraian dan analisis peraturan perundang-undangan Indonesia tentang pengelolaan wilayah laut/pesisir, bahwa masih terdapat ketidaksesuaian norma antara UU 32/2004 dan UU 27/2007 dengan prinsip negara kepulauan yang diatur dalan UNCLOS 1982. Prinsip negara kepulauan sangat menitikberatkan kesatuan wilayah laut nasional, sementara itu pengaturan wilayah pesisir dan pulau-pulau kecil di Indonesia membagi-bagi laut dalam wilayah kewenangan pemerintah kabupaten/kota yang berbedabeda. Hal ini tidak sejalah dengan spirit prinsip negara kepulauan. Disatu sisi Indonesia sangat berkeinginan untuk menerapkan prinsip berkelanjutan (sustainable principles) dalam pengelolaan wilayah laut/pesisirnya, di lain sisi pengaturan wilayah laut yang terdesentralisasi (DCZM) berbenturan atau tidak sesuai dengan komitmen Indonesia akan prinsip negara kepulauan yang menekankan pada kesatuan wilayah.

\section{DAFTAR PUSTAKA}

\section{Buku}

Anick, de Merffy, 2004, Ocean governance:

A Process in the Right Direction for the Effective Management of the Oceans, 18 Ocean Yearbook 163, 165.

A. Kumssa, J. Edralin, and W.O. Oyugi, 2003, A Needs Assessment Mission Report on Capacity Development in Local Governance: Africa-Asia Co-operation.
D.A. Rondinelli, and G.S. Cheema, Implementing Decentralisation Policies: An Introduction, in Cheema, G.S. and Rondinelli, D.A. (eds.)1983, Decentralisation and Development: Policy Implementation in Developing Countries.

P. Smoke, 2005, Decentralization in East Asia and the Pacific: Making Local Government Work. 
R.J. Bennet, 1990, Decentralization: Local

Governments and Markets: Towards

a Post Welfare Agenda.

Smith, B.C., 1985, Decentralization: The

Territorial Dimension of the State.

United Nations, 1962, Decentralization for

National and Local Development, ST/TAO/M/19 United Nations.

World Bank, 2006, Decentralization and

Subnational Regional Economics -

What, Why and Where, in World Bank

(ed.) Decentralization and Subnational regional Economics, 21.

\section{Naskah}

A. Agrawal and J.C. Ribot, 1993, Accountability in Decentralization: A Framework with South Asian and African Cases, 33 Journal of Developing Areas 473.

D.A. Rondinelli and J.R. Nellis, 1986, Accesing Decentralization Policies in Developing Countries: The Case of Some Cautios Optimism, 4 Development Policy Review 3.

J.C.Ribot, 2003, DemocraticDecentralization of Natural Resources: Institutional Choice and Discretionary Powers in Sub-Saharan Africa, 23 Public Administration and Development 53.

J. Laugo, 1995, Forms Decentralisation and their Implications for Education, 31 Comparative Education 5.

J. Samoff, 1992, Decentralisation:

The Politics of Intervention, 21

Development and Change 513.
T.A. Benjaminsen, 1997, Natural Resource Management, Paradigm Shifts and the Decentralization Reform in Mali, 25 Human Ecology 121.

Victor, Prescott, 2000, East Timor's Potential Maritime Boundaries, in Rothwell, Donald R and Tsamenyi, Martin (eds), The Maritime Dimensions of Independent East Timor, 79, 80.

Warwick, Gullett, 2010, Maritime Law in the Federal Context: Australian and Indonesian Provincial Maritime Zones, makalah dipresentasikan dalam International Seminar and Indonesian Forum on Ocean Law and Resources: Building Comprehensive Perspective on National Security and Sustainable Development, Brawijaya University, 17-19 May 2010.

\section{Konvensi Internasional}

Geneva Convention on Territorial Sea and Contiguous Zone 1958.

United Nations Convention on the Law of the Sea 1982.

Rio Declaration 1992.

\section{Peraturan Perundang-undangan}

Undang-undang Nomor 32/2004 tentang Pemerintahan Daerah, Lembar Negara Tahun 2004 Nomor 125, Tambahan Lembar Negara Nomor 4437.

Undang-undang No. 27/2007 tentang Pengelolaan Wilayah Pesisir dan 
Pulau-pulau Kecil, Lembar Negara Undang-undang No. 17/2008 tentang

Tahun 2007 Nomor 84, Tambahan

Lembar Negara Nomor 4739.
Pelayaran, Lembar Negara Tahun 2008 Nomor 64, Tambahan Lembar Negara Nomor 4846. 